\title{
TOUGHREACT Version 2.0: A Simulator for Subsurface Reactive Transport under Non-isothermal Multiphase Flow Conditions
}

\author{
Tianfu $\mathrm{Xu}^{*}$, Nicolas Spycher, Eric Sonnenthal, Guoxiang Zhang ${ }^{\dagger}$, Liange Zheng, and Karsten \\ Pruess
}

Earth Sciences Division, Lawrence Berkeley National Laboratory, 1 Cyclotron Road, Berkeley, CA 94720, USA

\begin{abstract}
TOUGHREACT is a numerical simulation program for chemically reactive nonisothermal flows of multiphase fluids in porous and fractured media, and was developed by introducing reactive chemistry into the multiphase fluid and heat flow simulator TOUGH2 V2. The first version of TOUGHREACT was released to the public through the U.S. Department of Energy's Energy Science and Technology Software Center (ESTSC) in August 2004. It is among the most frequently requested of ESTSC's codes. The code has been widely used for studies in $\mathrm{CO}_{2}$ geological sequestration, nuclear waste isolation, geothermal energy development, environmental remediation, and increasingly for petroleum applications. Over the last several years, many new capabilities have been developed, which were incorporated into Version 2 of TOUGHREACT. Major additions and improvements in Version 2 are discussed here, and two application examples are presented, (1) long-term fate of injected $\mathrm{CO}_{2}$ in a storage reservoir, and (2) biogeochemical cycling of metals in mining-impacted lake sediments.
\end{abstract}

Key words: Multi-phase flow, Reactive transport, TOUGHREACT, $\mathrm{CO}_{2}$ geological storage, Environmental remediation, Nuclear waste geological disposal.

\footnotetext{
${ }^{*}$ Corresponding author; Email address: Tianfu_Xu@lbl.gov (T.Xu).

${ }^{\dagger}$ Current address: Shell International E\&P Inc. Houston, TX 77079, USA.
} 


\section{Introduction}

TOUGHREACT is a numerical simulation program for chemically reactive nonisothermal flows of multiphase fluids in porous and fractured media (Xu and Pruess, 2001; Spycher et al., 2003; Sonnenthal et al., 2005; Xu et al., 2006; Xu, 2008; Zhang et al., 2008; Zheng et al., 2009). The program was written in Fortran 77 and developed by introducing reactive chemistry into the multiphase fluid and heat flow simulator TOUGH2 (Pruess, 2004). The program can be applied to one-, two- or three-dimensional porous and fractured media with physical and chemical heterogeneity. The code can accommodate any number of chemical species present in liquid, gas, and solid phases. A variety of subsurface thermal, physical, chemical, and biological processes are considered under a wide range of conditions of pressure, temperature, water saturation, ionic strength, and $\mathrm{pH}$ and Eh.

Processes for fluid flow and heat transport are the same as in the original TOUGH2. Transport of aqueous and gaseous species by advection and molecular diffusion is considered in both liquid (aqueous) and gas phases. Depending on computer memory and CPU performance, any number of chemical species in the liquid, gas, and solid phases can be accommodated. In the 2004 version (Version 1.0) of TOUGHREACT, aqueous complexation, acid-base, redox, gas dissolution/exsolution, and single-site cation exchange were considered under the local equilibrium assumption. Mineral dissolution and precipitation could proceed either subject to local equilibrium or kinetic conditions.

Over the last several years, many new capabilities have been developed within different research projects at Lawrence Berkeley National Laboratory. We have incorporated these new capabilities into Version 2.0 of TOUGHREACT. Major additions and improvements in Version 2.0 include

- Intra-aqueous reaction kinetics and biodegradation,

- Surface complexation models including double layer,

- Multi-site cation exchange,

- Improvements on reactive surface area algorithm for mineral-water reactions, and fugacity coefficient corrections for gas-water reactions,

- Improvements on mineral solid solution model that is an ideal model and only available for minerals reacting under kinetic constraints, 
- Improvements in coupling and mass balances between the chemistry and physics parts, including changes in rock and fluid properties due to reactions, and accounting for $\mathrm{CO}_{2}$ fixed as carbonates in the flow simulation (for using ECO2N module; Pruess and Spycher, 2007).

- Improvement on functionalities such as printouts of mineral reaction rates, and aqueous component and species concentrations in different user-selectable units,

- Improvements in computational efficiency.

TOUGHREACT V2.0 is written in FORTRAN 77 with some Fortran-90 extensions. It has been tested on various computer platforms, including Microsoft Windows- and Linux-based PCs, Apple Macintosh G4 and G5, and Intel-based computers. An effort was made for the TOUGHREACT source code to comply with the ANSIX3.9-1978 (FORTRAN 77) standard, and on most machines the code should compile using Fortran 95, Fortran 90, and some Fortran 77 compilers, and run without modification. TOUGHREACT (like TOUGH2 V2) requires 64-bit arithmetic ( 8 byte word length for floating point numbers) for successful execution; the code is intrinsically double-precision, to achieve 64-bit arithmetic on the commonly used 32-bit processors. The computer memory required by TOUGHREACT depends on the problem size such as numbers of grid blocks, aqueous and gaseous species, and minerals. Array dimensions are set in parameter statements in INCLUDE files.

The correct implementation, setup, problem formulation, and interpretation of the results of TOUGHREACT requires knowledge of the basic equations of multiphase non-isothermal fluid flow and transport in geologic media, and a basic understanding of the numerical solution of the equations that are used to describe these processes. In addition, the formulation of the geochemical problem requires familiarity with geochemical modeling and an in-depth understanding of the system that is being modeled and of the data used for input to the model. The model boundary conditions, time step length, convergence criteria, and grid properties are crucial elements for a realistic and accurate solution to a problem.

We first present the general formulation for solving flow, transport and reaction equations. To illustrate new features and applicability of TOUGHREACT Version 2, we then present two applications examples. 


\section{Mathematical Formulation}

TOUGHREACT uses a sequential iteration approach similar to Yeh and Tripathi (1991). After solution of the flow equations, the fluid velocities and phase saturations are used for chemical transport simulation. The chemical transport is solved on a component-by-component basis. The resulting concentrations obtained from solving transport equations are substituted into the chemical reaction model. The system of mixed equilibrium-kinetic chemical reaction equations is solved on a grid block by grid block basis by Newton-Raphson iteration. Optionally, the chemical transport and reactions are solved iteratively until convergence. An automatic time stepping scheme is implemented in TOUGHREACT, which includes an option to recognize "quasi-stationary states" (QSS; Lichtner, 1988) and perform a "large" time step towards the end of a QSS.

\subsection{Solution of Flow and Transport Equations}

The numerical solution of multi-phase fluid and heat flow proceeds as in TOUGH2. Space discretization is made by means of integral finite differences (IFD; Narasimhan and Witherspoon, 1976). Because chemical transport equations (derived from mass conservation) have the same structure as fluid and heat flow equations, the transport equations can be solved by the same numerical method. The basic mass- (for water, air, and chemical components) and energy- (for heat) balance equations are written in integral form for an arbitrary domain with a volume of $\mathrm{V}_{\mathrm{n}}$

$$
\mathrm{V}_{\mathrm{n}} \frac{\Delta \mathrm{M}_{\mathrm{n}}}{\Delta \mathrm{t}}=\sum_{\mathrm{m}} \mathrm{A}_{\mathrm{nm}} \mathrm{F}_{\mathrm{nm}}+\mathrm{V}_{\mathrm{n}} \mathrm{q}_{\mathrm{n}}
$$

where subscript $\mathrm{n}$ labels a grid block, subscript $\mathrm{m}$ labels grid blocks connected to grid block $\mathrm{n}, \Delta \mathrm{t}$ is time step size, and $M_{n}$ is the average mass or energy density in grid block n. Surface integrals are approximated as a discrete sum of averages over surface segments $A_{n m}, F_{n m}$ is the average flux (of mass or energy) over the surface segment $A_{n m}$ between volume elements $n$ and $m$, and $q_{n}$ is the average source/sink rate in grid block $n$ per unit volume. Time is discretized fully implicitly as a first-order finite difference to achieve unconditional stability. More detail on the 
discretization approach and the definition of the geometric parameters are given in $\mathrm{Xu}$ and Pruess (2001) and Pruess (2004). The IFD method gives a flexible discretization for geologic media that allows the use of irregular unstructured grids, which is well suited for simulation of flow, transport, and fluid-rock interaction in multi-region heterogeneous and fractured rock systems. For systems with regular grids, IFD is equivalent to conventional finite differences.

The time discretization of fluid and heat flow equations results in a set of coupled nonlinear algebraic equations for the unknown thermodynamic state variables in all grid blocks. These equations are solved by Newton-Raphson iteration as implemented in the original TOUGH2 simulator (Pruess, 2004). The set of coupled linear equations arising at each iteration step is solved iteratively by means of preconditioned conjugate gradient methods.

\subsection{Solution of Chemical System}

The equations for the chemical system are based on mass balance in terms of primary (basis) species. In contrast to aqueous equilibrium, species involved in kinetic reactions, such as redox couples, are independent and must be considered as primary species (Steefel and MacQuarrie, 1996). For example, for the reaction

$$
\mathrm{HS}^{-}+2 \mathrm{O}_{2}(\mathrm{aq})=\mathrm{SO}_{4}{ }^{2-}+\mathrm{H}^{+}
$$

under kinetic conditions, both $\mathrm{HS}^{-}$and $\mathrm{SO}_{4}{ }^{2-}$ must be placed in the primary species list. Thus, all redox reactions making use of these species must be decoupled in the input of the thermodynamic database.

Details on the formulation for solving the mixed equilibrium-kinetics system of equations are given in $\mathrm{Xu}$ (2008). Here we present the final Jacobian equations only. By denoting residuals of mass-balance of each component $\mathrm{j}$ as $F_{j}^{c}$ (which are zero in the limit of convergence), we have 


$$
\begin{aligned}
& F_{j}^{c}=\left(c_{j}-c_{j}^{0}\right) \quad \text { primary species } \\
& +\sum_{\mathrm{k}=1}^{\mathrm{N}_{\mathrm{x}}} v_{\mathrm{kj}}\left(\mathrm{c}_{\mathrm{k}}-\mathrm{c}_{\mathrm{k}}^{0}\right) \quad \text { equilibrium aqueous complexes } \\
& +\sum_{\mathrm{m}=1}^{\mathrm{N}_{\mathrm{p}}} \mathrm{v}_{\mathrm{mj}}\left(\mathrm{c}_{\mathrm{m}}-\mathrm{c}_{\mathrm{m}}^{0}\right) \quad \text { equilibrium minerals } \\
& -\sum_{\mathrm{n}=1}^{\mathrm{N}_{\mathrm{q}}} v_{\mathrm{nj}} \mathrm{r}_{\mathrm{n}} \Delta \mathrm{t} \quad \text { kinetic minerals } \\
& -\sum_{\mathrm{l}=1}^{\mathrm{N}_{\mathrm{a}}} \mathrm{v}_{\mathrm{lj}} \mathrm{r}_{1} \Delta \mathrm{t} \quad \text { kinetics among primary species } \\
& =\quad \begin{array}{ll}
\mathrm{j}=1 \ldots \mathrm{N}_{\mathrm{C}} \\
\mathrm{n}
\end{array}
\end{aligned}
$$

where superscript 0 represents time zero; $\Delta t$ is the time step; c are concentrations; subscripts $\mathrm{j}, \mathrm{k}$, $\mathrm{m}$, and $\mathrm{n}$ are the indices of primary species, aqueous complexes, minerals at equilibrium, and minerals under kinetic constraints, respectively; $\mathrm{N}_{\mathrm{c}}, \mathrm{N}_{\mathrm{x}}, \mathrm{N}_{\mathrm{p}}$, and $\mathrm{N}_{\mathrm{q}}$ are the number of corresponding species and minerals; $v_{\mathrm{kj}}, v_{\mathrm{mj}}$, and $v_{\mathrm{nj}}$ are stoichiometric coefficients of the primary species in the aqueous complexes, equilibrium, and kinetic minerals, respectively; $r_{n}$ is the kinetic rate of mineral dissolution and precipitation (positive for dissolution and negative for precipitation-units used here are moles of mineral per kilogram of water per time), for which a general multi-mechanism rate law was used (see next section and Appendix A); 1 is the aqueous kinetic reaction (including biodegradation) index, $\mathrm{N}_{\mathrm{a}}$ is total number of kinetic reactions among primary species, and $r_{1}$ is the kinetic rate which is in terms of one mole of product species per unit time. For product species, the stoichometric coefficients $v_{\mathrm{lj}}$ are positive, for reactant species, they are negative. The expression for $r_{1}$ is discussed in the next section and presented in Appendix B.

According to mass-action equations, concentrations of aqueous complexes $c_{k}$ can be expressed as functions of concentrations of the primary species $c_{j}$. Kinetic rates $r_{n}$ and $r_{1}$ are functions of $c_{j}$. (see Appendices A and B). No explicit expressions relate equilibrium mineral concentrations $c_{m}$ to $c_{j}$. Therefore, $N_{P}$ additional mass-action equations (one per mineral) are needed. Notice that gas dissolution/exsolution, cation exchange, and surface complexation are included in TOUGHREACT, but for simplicity the formulation is not shown here.

\subsection{Kinetic Rate Expressions}

A multiple mechanism rate law for mineral dissolution and precipitation is employed, which was reported in Xu et al. (2006), and is presented in Appendix A of this paper. A general 
rate expression for intra-aqueous kinetic reaction and biodegradation is incorporated into TOUGHREACT, which was given in Xu (2008), and is also presented here in Appendix B.

Temporal changes in porosity and permeability due to mineral dissolution and precipitation can modify fluid flow path characteristics. This feedback between flow and chemistry is considered. Changes in porosity are calculated from changes in mineral volume fractions. Several porosity-permeability relationships are implemented in TOUGHREACT. Details on the formulation are given in Xu et al. (2006).

\section{Treatment of Fractured Rock and Heterogeneous Media}

\subsection{Multiple Interacting Continua}

For chemical transport in variably saturated fractured rocks, global fluid flow and transport of aqueous and gaseous species occurs primarily through a network of interconnected fractures, while chemical species may penetrate into tight matrix blocks primarily through relatively slow diffusive transport in gas and liquid phases. Methods developed for fluid flow in fractured rock can be applied to geochemical transport.

The method of "multiple interacting continua" (MINC) is used to resolve "global" flow and transport of chemicals in the fractured rock and its interaction with "local" exchange between fractures and matrix rock. This method was developed by Pruess and Narasimhan (1985) for fluid and heat flow in fractured porous media. The extension of the MINC method to reactive geochemical transport is described in detail by Xu and Pruess (2001). It is well-known that in the case of reactive chemistry, diffusive fluxes may be controlled by reactions occurring near (within millimeters of) the fracture walls. The resolution of concentration gradients in matrix blocks is achieved by appropriate subgridding. The MINC concept is based on the notion that changes in fluid pressures, temperatures, and chemical concentrations propagate rapidly through the fracture system, while invading the tight matrix blocks only slowly. Therefore, changes in matrix conditions will be (locally) controlled by the distance from the fractures and can then be modeled by means of one-dimensional strings of nested grid blocks (Figure 1).

\subsection{Multi-Region Model}

Similar to "multiple interacting continua" (MINC) for fractured rock, multi-region concepts can be employed in TOUGHREACT for modeling biogeochemical transport in heterogeneous porous media (Gwo et al., 1996; Xu, 2008). The multi-region model was 
proposed to account for hierarchical pore structures, the resultant widely distributed pore water velocities, and the effect of local-scale and field-scale heterogeneities on mass transport. Pore regions can either be physically identified as discrete features, or be experimentally determined by separation of water retention curves according to pore classification schemes. Note that the concept of "region" here is not a "regional model" that generally implies a scale measured in square kilometers. The concept being utilized is a sub-REV concept.

An application of the multi-region model was presented in $\mathrm{Xu}$ (2008) to denitrification and sulfate reduction (Figure 2). The applicability was evaluated by comparison with column experiments. The matches with measured nitrate and sulfate concentrations were achieved by adjusting the interfacial area between mobile and immobile regions. The match and parameter calibration suggest that TOUGHREACT is not only a useful interpretative tool for biogeochemical experiments, but also can produce insight into the processes and parameters of microscopic diffusion and their interplay with biogeochemical reactions.

The basic idea behind multiple interacting continua or multi-region approaches is to model dispersion by explicitly resolving domains with different advective velocities through appropriate spatial discretization (gridding). This approach is applicable for heterogeneous media in which regions of higher permeability form spatially-extensive correlated structures. Note that hydrodynamic dispersion is not explicitly accounted in TOUGHREACT, which arises from an interplay between non-uniform advection and molecular diffusion. In geologic media, velocities of fluid parcels are spatially variable due to heterogeneities on multiple scales, all the way from the pore-scale to basin-scale. The process is often represented by a Fickian diffusion analog (convection-dispersion equation), which has fundamental flaws and limitations. Details on the dispersion are discussed in Xu and Pruess (2001).

\section{Application Examples}

TOUGHREACT V2.0 has been applied to a wide variety of geological and environmental problems. An application to denitrification and sulfate reduction was presented in $\mathrm{Xu}$ (2008). The possible mobilization of inorganic constituents such as $\mathrm{Pb}$ and $\mathrm{As}$ in groundwater in response to $\mathrm{CO}_{2}$ leakage from deep geological storage has been modeled in Zheng et al. (2009), who considered aqueous complexation, mineral dissolution/precipitation, and desorption/adsorption via surface complexation using double layer model. Here, we discuss two examples: (1) long-term fate and transport of injected $\mathrm{CO}_{2}$ in the storage reservoir using a 2- 
$\mathrm{D}$ radial flow model; and (2) biogeochemical cycling of iron and other heavy metals $(\mathrm{Zn}, \mathrm{Pb}, \mathrm{Cu}$ ) in sediments of Lake Coeur d'Alene, Idaho, which have been heavily impacted by mining activities.

\subsection{Long-Term Fate of Injected $\mathrm{CO}_{2}$}

Concern over the consequences of global warming due to increasing levels of anthropogenic carbon dioxide $\left(\mathrm{CO}_{2}\right)$ in the atmosphere has led to a variety of proposals to curtail, if not prevent, further increases. One such approach is to inject $\mathrm{CO}_{2}$, captured from stationary sources (such as fossil-fuel power plants) into deep saline geologic formations. The response of deep formations to $\mathrm{CO}_{2}$ injection will depend on many factors, including formation permeability and porosity, the presence of heterogeneities such as faults and layers of high or low permeability, the physical and chemical characteristics of the brines, and the nature of the mineral phases that are present. A great deal of specific and detailed information will be required to assess the feasibility of storing $\mathrm{CO}_{2}$ in a brine formation at any particular site, and to develop engineering designs for $\mathrm{CO}_{2}$ storage systems. Here, a generic two-dimensional (2-D) radial model applicable to conditions encountered near the Texas gulf coast was used to study the temporal evolution and spatial distribution of the injected $\mathrm{CO}_{2}$ and the subsequent physical and chemical changes.

Note that new chemical processes added in Version 2.0 were not needed for the modeling this example of geologic $\mathrm{CO}_{2}$ sequestration (compared to Version 1.0). However, some improvements were used such as in fugacity coefficient corrections for gas-water reactions, in coupling and mass balances between the chemistry and physics parts including changes in rock and fluid properties due to reactions, in accounting for $\mathrm{CO}_{2}$ fixed as carbonates in the flow simulation, on functionalities of result printouts, and in computational efficiency.

\section{Fluid flow conditions}

The 2-D radial model was a sandstone formation of $40 \mathrm{~m}$ thickness with a cylindrical geometrical configuration (Figure 3). The hydrogeological parameters used are listed in Table 1, the formation was assumed as homogenous initially. The petrophysical characteristics such as porosity and permeability were taken from the storage formation of the upper $\mathrm{C}$ sandstone of the Frio $\mathrm{CO}_{2}$ test site (Hovorka et al., 2006; Doughty et al., 2008). The vertical permeability is one order of magnitude smaller than the horizontal one. A hydrostatic pressure distribution over the 
depth was specified initially. The shale caprock was assumed impermeable and non-reactive for the present study of coupled processes in the storage reservoir. We did not use the geometry of the Frio Pilot test flow model, because the reservoir is only $5.5 \mathrm{~m}$ thick and only $1600 \mathrm{t}$ of $\mathrm{CO}_{2}$ were injected (Freifeld et al., 2005), which may not represent a realistic $\mathrm{CO}_{2}$ storage reservoir conditions.

For numerical simulation, in the vertical direction a total of 20 model layers were used with a constant spacing of $2 \mathrm{~m}$. In the horizontal direction, a radial distance of $100 \mathrm{~km}$ was modeled with a radial spacing that increases gradually away from the injection well. A total of 56 radial grid elements were used. The volume of the outer grid element is specified a large value of $10^{30} \mathrm{~m}^{3}$, representing an infinite lateral boundary for constant pressure, temperature and concentrations. $\mathrm{CO}_{2}$ injection was applied at the bottom portion over $8 \mathrm{~m}$ thickness with a constant rate of $20 \mathrm{~kg} / \mathrm{s}$ (corresponding to $0.64 \mathrm{Mt} /$ year) for a period of 10 years. Our 2-D radial model of fluid flow and geochemical transport was simulated for a period for 1,000 years, which is a relevant time scale for $\mathrm{CO}_{2}$ geological sequestration. We considered a system with initially homogeneous porosity and permeability. Changes in porosity and permeability due to mineral alteration will seed fluid dynamics instabilities and promote convective mixing.

\section{Geochemical system}

The initial rock mineralogical composition was taken from $\mathrm{Xu}$ et al. (2007), which may be representative of US Gulf Coast sandstone formations (Table 2). Calcite was assumed to react with aqueous species at local equilibrium because its reaction rate is typically quite rapid. Dissolution and precipitation of other minerals are kinetically-controlled. A multiple mechanism rate law is used, which is given in Appendix A. Kinetic parameters are the same as in a previous study (Xu et al., 2007), and are given in Appendix B.

The initial water chemical composition (Table 3) represents a $\mathrm{NaCl}$-dominated brine of a sample from the Frio test site (Kharaka et al., 2009). A temperature of $75^{\circ} \mathrm{C}$ was used throughout, which may represent temperature at a depth of about $2 \mathrm{~km}$, given a land surface temperature of $15^{\circ} \mathrm{C}$ and a geothermal gradient of $30^{\circ} \mathrm{C} / \mathrm{km}$. Prior to simulating reactive transport, batch geochemical modeling of water-rock interaction was performed to equilibrate the measured chemical composition with the primary minerals listed in Table 2 at a $\mathrm{CO}_{2}$ gas pressure of 0.1 bar and a temperature of $75^{\circ} \mathrm{C}$. The background (initial) $\mathrm{CO}_{2}$ gas pressure was chosen to match the measured $\mathrm{pH}$. A reasonably short simulation time (10 years in the present study) is needed to obtain nearly steady-state aqueous solution composition for the reactive transport simulation. In 
our previous studies such as in Xu et al. (2007), the initial water chemistry for reactive transport simulation was obtained using the same procedure, but starting from a solution of $1 \mathrm{M} \mathrm{NaCl}$ with very low concentrations for other aqueous components, because Frio water sample was not available when the previous simulation was performed.

\section{Results and discussion}

The supercritical $\mathrm{CO}_{2}$ fluid (called "gas" here for simplicity) injected near the bottom of the storage formation migrates upward rapidly by buoyancy forces because the density of supercritical $\mathrm{CO}_{2}$ phase is lower than that of aqueous phase (Figure 4). A small fraction of $\mathrm{CO}_{2}$ gas is trapped in the porous rock as residual gas after injection. The residual gas trapping keeps $\mathrm{CO}_{2}$ dissolving into brine and precipitating carbonate minerals, and gradually disappears at the bottom of the reservoir. Over time most of the free $\mathrm{CO}_{2}$ gas accumulates below the caprock, and then spreads laterally. To about $60 \mathrm{~m}$ radial distance rock pores are completely filled by $\mathrm{CO}_{2}$ gas at 10 years (complete water drying out zone). After injection ends (at 10 years), groundwater reinvades previously dried-out zones and chemical reactions (dissolution and precipitation) between the dissolved $\mathrm{CO}_{2}$ and minerals proceed.

The simulated total dissolved $\mathrm{CO}_{2}$ concentrations after $1000 \mathrm{yr}$ are presented in Figure 5a. With the migration of $\mathrm{CO}_{2}$ gas, the concentration of dissolved $\mathrm{CO}_{2}$ rapidly increases to larger than $1 \mathrm{~mol} / \mathrm{kg} \mathrm{H}_{2} \mathrm{O}$ in the two-phase region. The injected $\mathrm{CO}_{2}$ is dissolved in the surrounding formation water, forming $\mathrm{H}_{2} \mathrm{CO}_{3}, \mathrm{HCO}_{3}{ }^{-}$, and $\mathrm{CO}_{3}{ }^{2-}$, and decreasing $\mathrm{pH}$. Then, the increased acidity induces dissolution of many of the primary host rock minerals (discussed later). The mineral dissolution increases concentrations of cations such as $\mathrm{Na}^{+}, \mathrm{Ca}^{2+}, \mathrm{Mg}^{2+}$, and $\mathrm{Fe}^{2+}$, which in turn form aqueous complexes with the bicarbonate ion such as $\mathrm{NaHCO}_{3}, \mathrm{CaHCO}_{3}{ }^{+}$, $\mathrm{MgHCO}_{3}{ }^{+}$, and $\mathrm{FeHCO}_{3}{ }^{+}$. Over time they tend to increase dissolved $\mathrm{CO}_{2}$ (solubility) and enhance solubility trapping. Figure 5a shows a "fingering" flow patterns near the bottom of the $\mathrm{CO}_{2}$ plume. This arises from advection in the aqueous phase that is triggered by an increase in density due to $\mathrm{CO}_{2}$ dissolution.

Minerals such as oligoclase and chlorite dissolve in the two-phase region and near the front of the single aqueous-phase zone, supplying reactants for carbonate mineral precipitation. Some amount of siderite (Figure 6a), and significant amount of ankerite (Figure 6b) precipitate, sequestering injected $\mathrm{CO}_{2}$ (mineral trapping). At the same time, clay minerals such as smectiteNa precipitate. 
Changes in porosity are calculated from variations in mineral volume fractions. Porosity increases slightly in the two-phase region due to dominant mineral dissolution (Figure 7) caused by low $\mathrm{pH}$. In contrast, porosity decreases at the front of the aqueous-phase because of higher $\mathrm{pH}$ and carbonate mineral precipitation. A simple cubic Kozeny-Carman grain model was used to calculate associated changes in permeability. The pattern of permeability change is similar to that of porosity.

Evolution of amounts of $\mathrm{CO}_{2}$ stored in the three phases over time is presented in Figure 8. During the $\mathrm{CO}_{2}$ injection period (0-10 years), a large amount of injected $\mathrm{CO}_{2}$ remains as a free supercritical phase. After the stop of injection, the mass of $\mathrm{CO}_{2}$ dissolved in the formation water gradually increases because of the upward and horizontal migration of $\mathrm{CO}_{2}$ plume and the convective mixing between $\mathrm{CO}_{2}$-saturated water and unsaturated water. $\mathrm{CO}_{2}$ mineral trapping starts at about 50 years when primary mineral dissolution has neutralized the $\mathrm{pH}$, and subsequently increases gradually (almost linearly) with time. After 1,000 years, $43 \%$ of the injected $\mathrm{CO}_{2}$ is stored in the gas phase, $28 \%$ in the aqueous, and $29 \%$ in the solid (mineral) phase.

As discussed in $\mathrm{Xu}$ et al. (2007), the modeling provides valuable insights regarding the physical and chemical consequences of $\mathrm{CO}_{2}$ injection in the subsurface environment. Note that the results are constrained by parameter uncertainties. Mineral alteration and $\mathrm{CO}_{2}$ trapping capability depend on the primary mineral composition. Precipitation of siderite and ankerite requires $\mathrm{Fe}^{2+}$, which can be supplied by the dissolution of iron-bearing minerals, such as chlorite, or by reduction of $\mathrm{Fe}^{3+}$ in small amounts of hematite. Variation in $\mathrm{Ca}$ content in plagioclase significantly affects carbonate mineral precipitation, and thus $\mathrm{CO}_{2}$ mineral trapping. The time required for mineral alteration and $\mathrm{CO}_{2}$ sequestration depends on the rates of mineral dissolution and precipitation.

If carbon dioxide stored in deep saline aquifers were to leak into an overlying aquifer containing potable groundwater, the intruding $\mathrm{CO}_{2}$ would change the geochemical conditions and cause secondary effects mainly induced by changes in $\mathrm{pH}$. In particular, hazardous trace elements such as lead and arsenic, which may be present in the aquifer host rock, could be mobilized. TOUGHREACT Version 2.0 has been used to evaluate the potential risks to potable water quality by analyzing mechanisms through which lead and arsenic might be mobilized by intrusion of $\mathrm{CO}_{2}$ (Zheng et al., 2009). The chemical reactions considered by Zheng et al. include aqueous complexation, mineral dissolution/precipitation, and desorption/adsorption via surface complexation using double layer model. Simulation results indicate that desorption/adsorption 
could be the most important process controlling the fate of hazardous trace elements mobilized by $\mathrm{CO}_{2}$ leakage when sorbing minerals are present. The relative importance of dissolution/precipitation versus desorption/adsorption is controlled by many factors, including sorption parameters and aquifer mineralogy, reaction kinetics, aqueous complexation processes, and mineral solubility constants.

\subsection{Biogeochemical Cycling of Metals in Mining-impacted Lake Sediments}

This example builds on the work presented by Sengör et al. (2007a,b) on modeling the diffusive transport of heavy metals $(\mathrm{Zn}, \mathrm{Pb}, \mathrm{Cu})$ in the sediments of Lake Coeur d'Alene, Idaho. Details on the conceptual model and implemented biogeochemical reaction network are given in Sengör et al. (2007a,b) and summarized below.

The sediments of Lake Coeur d'Alene have been heavily impacted by mining activities and, as a result, contain elevated concentrations of iron and heavy metals. These sediments contain significant amounts of iron hydroxides, primarily as ferrihydrite (Toevs et al., 2006; Moberly et al. 2009), together with quartz and siderite as major minerals. The microbial reductive dissolution of iron hydroxides in the sediments is thought to lead to the release of metals sorbed onto these mineral phases, generating benthic fluxes of metals from the sediments to the lake water (Balistrieri, 1998; Kuwabara et al., 2003). Deeper into the sediments, metals mobilized by reductive dissolution become immobilized by reaction with biogenic sulfide to form sulfide minerals. These coupled processes are simulated for a 1D sediment column under redox disequilibrium conditions (Figure 9).

The model setup and input data are essentially unchanged from the model presented earlier (Sengör et al. 2007b), which was built using PHREEQC (Parkhurst and Appelo, 1999). The model incorporates a multicomponent biotic reaction network with multiple terminal electron acceptors (TEA) (Table 4), diffusive transport, mineral precipitation and dissolution, and surface complexation. The switch from one TEA to the next is implemented using inhibition factors $\left(K^{\text {in }}\right.$ in Table 4$)$ in the manner proposed by Van Cappellen and Gaillard (1996). We have added to the original 1-D model the effect of sedimentation, approximated by advecting sediment solids and pore water downward at a rate decreasing with depth to mimic compaction. In addition to species originally considered for sorption onto Fe hydroxides $\left(\mathrm{Zn}^{2+}, \mathrm{Cu}^{2+}, \mathrm{Cu}^{+}, \mathrm{Pb}^{2+}\right.$, $\mathrm{H}^{+}, \mathrm{Ca}^{2+}, \mathrm{Mg}^{2+}, \mathrm{SO}_{4}^{2-}$; Dzombak and Morel, 1990), $\mathrm{Fe}^{2+}$ surface complexation (Liger et al., 1999) was also added to the original model. Note that rate laws for the various biotic reactions 
(Table 4) are multiplied by a thermodynamic affinity term $(1-Q / K)$, where $Q$ and $K$ are the ion activity product and the equilibrium constant, respectively, of the reaction) that effectively shuts down the reaction if/when equilibrium is reached (at which point $Q=K$ ).

The top model boundary is located at the lake water-sediment interface. It is set at a fixed composition equal to the (measured) composition of lake water equilibrated with sorption sites on ferrihydrite. Transport is entirely diffusive, with a closed bottom model boundary. The simulated 1D sediment column is $45 \mathrm{~cm}$ long, with a grid spacing of $0.5 \mathrm{~cm}$ for the first top 8 cells, then increasing to $1 \mathrm{~cm}$ through the remainder of the column. The sedimentation rate is set at $2 \mathrm{~cm} / \mathrm{yr}$ at the top of the column (Horowitz et al., 1995), and linearly decreasing to zero at the base of the column. The diffusion coefficient is low $\left(\sim 4 \times 10^{-6} \mathrm{~cm}^{2} / \mathrm{s}\right)$, reflecting very fine-grained sediments (Balistrieri, 1998). Simulations are carried out for a period of about 5 years, after which nearly steady conditions prevail.

The same aqueous reaction network is modeled as in Sengör et al. (2007b) (Tables 4 and 5). Higher in the sediment column, iron-reducing bacteria reduce iron hydroxides:

$$
8 \mathrm{Fe}(\mathrm{OH})_{3(\mathrm{~s})}+\mathrm{CH}_{3} \mathrm{COO}^{-}+15 \mathrm{H}^{+} \rightarrow 8 \mathrm{Fe}^{2+}+2 \mathrm{HCO}_{3}^{-}+20 \mathrm{H}_{2} \mathrm{O}
$$

This reaction leads to the release of sorbed metals $(\mathrm{Zn}, \mathrm{Cu}, \mathrm{Pb})$. At depth, sulfate reducing bacteria produce sulfide, which can react with Fe(II) and other metals to form precipitates:

$$
\mathrm{Fe}^{2+}+\mathrm{CH}_{3} \mathrm{COO}^{-}+\mathrm{SO}_{4}{ }^{2-} \rightarrow \mathrm{FeS}_{(\mathrm{s})}+2 \mathrm{HCO}_{3}^{-}+\mathrm{H}^{+}
$$

Reactions (4) and (5) represent overall reactions that proceed though the coupling of the reaction network (Table 4) with ferrihydrite (modeled as $\left.\mathrm{Fe}(\mathrm{OH})_{3}\right)$ and mackinawite (FeS, disordered) reacting at equilibrium. Sphalerite $(\mathrm{ZnS})$, galena $(\mathrm{PbS})$ and chalcocite $\left(\mathrm{Cu}_{2} \mathrm{~S}\right)$ are included as "proxy" phases precipitating under kinetic constraints to provide a sink for heavy metals. Siderite $\left(\mathrm{FeCO}_{3}\right)$ is also included as a phase reacting under kinetic constraints. The only minerals initially present in the modeled column are ferrihydrite and siderite, which are observed throughout the lake sediments in significant amounts (Toevs et al., 2006), likely from both detrital and diagenetic origins (Table 6).

Simulations are started with (oxic) lake water (Table 7) initially throughout the column. A redox stratification eventually develops through the microbial reaction network (Table 4), from oxic lake-water conditions at the top of the column to sulfate-reducing conditions at the 
bottom of the column. Kinetic reaction parameters are initially obtained from the literature, then are adjusted as necessary to best match the model results to field data (Winowiecki, 2002) (Figure 10). Note that the electron donor is taken as acetate, which is reported in pore water at $\sim 150 \mu \mathrm{M}$ and is assumed un-limiting.

Modeled concentration trends for key species are generally consistent with measured data (Figure 10). The behavior of heavy metals is driven by desorption at shallow depth, accompanied by the microbial reductive dissolution of ferrihydrite, and precipitation with biogenic sulfide deeper into the sediment column. In the present case, the precipitation rates of heavy metal sulfides are kept relatively low and roughly adjusted to yield metal concentrations within the observed range. A delicate balance is predicted between the competition of $\mathrm{FeS}$ and $\mathrm{FeCO}_{3}$ precipitation for $\mathrm{Fe}(\mathrm{II})$, and the competition of soluble (bi)sulfide complexes and sulfide mineral precipitation for biogenic sulfide. Results compare well with the original PHREEQC model developed by Sengör et al. (2007b), with small differences resulting from processes added to the original model, namely Fe(II) sorption onto ferrihydrite and sedimentation, and differences in the affinity terms on the kinetic rate laws of minerals (Table 6). This example provides a typical application of TOUGHREACT V2.0 to a complex reaction network in a shallow, lowtemperature environmental system at redox disequilibrium.

\section{Conclusions}

A non-isothermal reactive transport program, TOUGHREACT, has been developed, which allows comprehensive modeling of chemical interactions between liquid, gaseous and solid phases that are coupled to solute transport and subsurface multiphase fluid and heat flow. The program is applicable to one-, two-, or three-dimensional geologic domains with physical and chemical heterogeneity, and can be applied to a wide range of subsurface conditions of pressure, temperature, water saturation, ionic strength, and $\mathrm{pH}$ and Eh. The program can be applied to a variety of problems, including contaminant transport and environmental remediation, natural groundwater quality evolution under ambient conditions, assessment of nuclear waste disposal sites, sedimentary diagenesis and $\mathrm{CO}_{2}$ sequestration in deep saline formations, mineral deposition such as supergene copper enrichment, and mineral alteration and silica scaling in hydrothermal systems under natural and production conditions.

The examples discussed in this paper demonstrate that TOUGHREACT is a useful tool for modeling non-equilibrium physical and chemical processes in natural or engineered 
subsurface systems. Important challenges remaining for future research include consistent thermodynamic and kinetic data, ion activity models for conditions with high ionic strength fluids, description of rock-fluid interactions in the absence of an aqueous phase.

\section{Acknowledgment}

The development of TOUGHREACT was supported by various DOE program offices, and documentation of Version 2.0 was supported by the Zero Emission Research and Technology project (ZERT), of the U.S. Department of Energy under Contract No. DE-AC02-05CH11231 with Lawrence Berkeley National Laboratory.

\section{Appendix A. Kinetic rate law for mineral dissolution and precipitation}

The general rate expression used in TOUGHREACT is taken from Lasaga et al. (1994):

$$
\mathrm{r}_{\mathrm{n}}= \pm \mathrm{k}_{\mathrm{n}} \mathrm{A}_{\mathrm{n}}\left|1-\left(\frac{\mathrm{Q}_{\mathrm{n}}}{\mathrm{K}_{\mathrm{n}}}\right)^{\theta}\right|^{\eta}
$$

where $\mathrm{n}$ denotes kinetic mineral index, positive values of $r_{n}$ indicate dissolution, and negative values precipitation, $\mathrm{k}_{\mathrm{n}}$ is the rate constant (moles per unit mineral surface area and unit time) which is temperature dependent, $A_{n}$ is the specific reactive surface area per $\mathrm{kg} \mathrm{H}_{2} \mathrm{O}, \mathrm{K}_{n}$ is the equilibrium constant for the mineral-water reaction written for the destruction of one mole of mineral $\mathrm{n}$, and $\mathrm{Q}_{\mathrm{n}}$ is the reaction quotient. The parameters $\theta$ and $\eta$ must be determined from experiments; usually, but not always, they are taken equal to one.

For many minerals, the kinetic rate constant $\mathrm{k}$ can be summed from three mechanisms (Palandri and Kharaka, 2004), or 


$$
\begin{aligned}
\mathrm{k}= & \mathrm{k}_{25}^{\mathrm{nu}} \exp \left[\frac{-\mathrm{E}_{\mathrm{a}}^{\mathrm{nu}}}{\mathrm{R}}\left(\frac{1}{\mathrm{~T}}-\frac{1}{298.15}\right)\right]+ \\
& \mathrm{k}_{25}^{\mathrm{H}} \exp \left[\frac{-\mathrm{E}_{\mathrm{a}}^{\mathrm{H}}}{\mathrm{R}}\left(\frac{1}{\mathrm{~T}}-\frac{1}{298.15}\right)\right] \mathrm{a}_{\mathrm{H}}^{\mathrm{n}_{\mathrm{H}}}+ \\
& \mathrm{k}_{25}^{\mathrm{OH}} \exp \left[\frac{-\mathrm{E}_{\mathrm{a}}^{\mathrm{OH}}}{\mathrm{R}}\left(\frac{1}{\mathrm{~T}}-\frac{1}{298.15}\right)\right] \mathrm{a}_{\mathrm{OH}}^{\mathrm{n}_{\mathrm{OH}}}
\end{aligned}
$$

where superscripts or subscripts nu, $\mathrm{H}$, and $\mathrm{OH}$ indicate neutral, acid, and base mechanisms, respectively, $\mathrm{E}_{\mathrm{a}}$ is the activation energy, $\mathrm{k}_{25}$ is the rate constant at $25^{\circ} \mathrm{C}, \mathrm{R}$ is gas constant, $\mathrm{T}$ is absolute temperature, $\mathrm{a}$ is the activity of the species; and $\mathrm{n}$ is an exponent (constant). The rate constant $\mathrm{k}$ can be also dependent on other species such as $\mathrm{Al}^{3+}$ and $\mathrm{Fe}^{3+}$. Two or more species may be involved in one mechanism. A general form of species dependent rate constants (extension of Equation A.2) is implemented in TOUGHREACT as

$$
\begin{aligned}
& \mathrm{k}=\mathrm{k}_{25}^{\mathrm{nu}} \exp \left[\frac{-\mathrm{E}_{\mathrm{a}}^{\mathrm{nu}}}{\mathrm{R}}\left(\frac{1}{\mathrm{~T}}-\frac{1}{298.15}\right)\right]+ \\
& \sum_{\mathrm{i}} \mathrm{k}_{25}^{\mathrm{i}} \exp \left[\frac{-\mathrm{E}_{\mathrm{a}}^{\mathrm{i}}}{\mathrm{R}}\left(\frac{1}{\mathrm{~T}}-\frac{1}{298.15}\right)\right] \prod_{\mathrm{j}} \mathrm{a}_{\mathrm{ij}}^{\mathrm{n}_{\mathrm{ij}}}
\end{aligned}
$$

where superscripts or subscripts $i$ is the additional mechanism index, and $j$ is species index involved in one mechanism that can be primary or secondary species. TOUGHREACT currently considers up to five additional mechanisms and up to five species involved in each mechanism.

\section{Appendix B. Rate expression for Intra-aqueous kinetics and biodegradation}

A general rate expression for intra-aqueous kinetic reaction and biodegradation has been incorporated into TOUGHREACT. Following the expression of Curtis (2003) and adding multiple mechanisms (or pathways), a general rate law used is: 


$$
r_{i}=\sum_{s=1}^{M}\left[\begin{array}{ll}
k_{i, s} & \text { rate constant } \\
\times \prod_{j=1}^{N_{1}}\left(\gamma_{j}^{v_{i, j}} C_{j}^{v_{i, j}}\right) & \text { product terms } \\
\times \prod_{k=1}^{N_{m}} \frac{C_{i, k}}{K_{M i, k}+C_{i, k}} & \text { Monod terms } \\
\times \prod_{p=1}^{N_{p}} \frac{I_{i, p}+C_{i, p}}{I_{i, p}} & \text { inhibition terms }
\end{array}\right]
$$

where $r_{i}$ is the reaction rate of the $i$-th reaction, $M$ is the number of mechanisms or pathways, $s$ is the mechanism counter, $\mathrm{k}$ is a rate constant, (often denoted $v_{\max }$, maximum specific growth constant for biodegradation), $\gamma_{j}$ is the activity coefficient of species $\mathrm{j}, \mathrm{C}_{\mathrm{j}}$ is the concentration of species $\mathrm{j}$ (with biodegradation, the product term is usually biomass concentration), $\mathrm{v}_{\mathrm{i}, \mathrm{j}}$ is a stoichiometric coefficient, $\mathrm{N}_{1}$ is the number of reacting species in the forward rate term (called product terms), $\mathrm{N}_{\mathrm{m}}$ is the number of Monod factors (Monod terms), $\mathrm{C}_{\mathrm{i}, \mathrm{k}}$ is the concentration of the k-th Monod species, $\mathrm{C}_{\mathrm{i}, \mathrm{p}}$ is the concentration of the p-th inhibiting species, $\mathrm{K}_{\mathrm{Mi}, \mathrm{k}}$ is the k-th Monod half-saturation constant of the i-th species, $N_{P}$ is the number of inhibition factors (inhibition terms), and $\mathrm{I}_{\mathrm{i}, \mathrm{p}}$ is the p-th inhibition constant. Equation (B.1) accounts for multiple mechanisms and multiple products, Monod, and inhibition terms, which can cover many rate expressions

\section{Appendix C. Parameters used for kinetic rate law}

Calcite was assumed to react with aqueous species at local equilibrium because its reaction rate is typically quite rapid. Dissolution and precipitation of other minerals are kinetically-controlled. Kinetic rates are a product of the rate constant and reactive surface area (Eq. A.1 in Appendix A). Multiple mechanisms (including neutral, acid and base) are used for dissolution of minerals (Eqs. A.2 and A.3 in Appendix A). Kinetic parameters including rate constant $\left(\mathrm{k}_{25}\right)$, the activation energy $\left(E_{a}\right)$, and the power term (n) for each mechanism are given in Table C.1. The thermodynamic data, kinetic parameters, and reactive surface areas used are discussed in $\mathrm{Xu}$ et al. (2007). 
Table C.1. Parameters for calculating kinetic rate constants of minerals. Note that: (1) all rate constants are listed for dissolution; (2) A is specific surface area, $\mathrm{k}_{25}$ is kinetic constant at $25^{\circ} \mathrm{C}$, $\mathrm{E}$ is activation energy, and $\mathrm{n}$ is the power term (Eq. A.2); (3) the power terms $\mathrm{n}$ for both acid and base mechanisms are with respect to $\mathrm{H}^{+}$; (4) for pyrite, the neutral mechanism has $\mathrm{n}$ with respect to $\mathrm{O}_{2}(\mathrm{aq})$, the acid mechanism has two species involved: one $\mathrm{n}$ with respect to $\mathrm{H}^{+}$and another $\mathrm{n}$ with respect to $\mathrm{Fe}^{3+}$.

\begin{tabular}{|c|c|c|c|c|c|c|c|c|c|}
\hline \multirow[t]{3}{*}{ Mineral } & \multirow{3}{*}{$\begin{array}{l}A \\
\left(\mathrm{~cm}^{2} / \mathrm{g}\right)\end{array}$} & \multicolumn{8}{|c|}{ Parameters for kinetic rate law } \\
\hline & & \multicolumn{2}{|c|}{ Neutral mechanism } & \multicolumn{3}{|c|}{ Acid mechanism } & \multicolumn{3}{|c|}{ Base mechanism } \\
\hline & & $\begin{array}{l}k_{25} \\
\left(\mathrm{~mol} / \mathrm{m}^{2} / \mathrm{s}\right)\end{array}$ & $\begin{array}{l}E_{a} \\
(\mathrm{KJ} \\
/ \mathrm{mol})\end{array}$ & $k_{25}$ & $E_{a}$ & $n\left(H^{+}\right)$ & $k_{25}$ & $E_{a}$ & $n\left(H^{+}\right)$ \\
\hline Calcite & \multicolumn{9}{|c|}{ At local equilibrium } \\
\hline Quartz & 9.1 & $1.0 \times 10^{-14}$ & 87.7 & & & & & & \\
\hline Kaolinite & 108.7 & $7.0 \times 10^{-14}$ & 22.2 & $4.9 \times 10^{-12}$ & 65.9 & 0.777 & $8.9 \times 10^{-18}$ & 17.9 & -0.472 \\
\hline Illite & 108.7 & $1.7 \times 10^{-13}$ & 35 & $1.0 \times 10^{-11}$ & 23.6 & 0.34 & $3.0 \times 10^{-17}$ & 58.9 & -0.4 \\
\hline Oligoclase & 9.1 & $1.4 \times 10^{-12}$ & 69.8 & $2.1 \times 10^{-10}$ & 65 & 0.457 & & & \\
\hline K-feldspar & 9.1 & $3.9 \times 10^{-13}$ & 38 & $8.7 \times 10^{-11}$ & 51.7 & 0.5 & $6.3 \times 10^{-22}$ & 94.1 & -0.823 \\
\hline Na-smectite & 108.7 & $1.7 \times 10^{-13}$ & 35 & $1.0 \times 10^{-11}$ & 23.6 & 0.34 & $3.0 \times 10^{-17}$ & 58.9 & -0.4 \\
\hline Chlorite & 9.1 & $3.0 \times 10^{-13}$ & 88 & $7.8 \times 10^{-12}$ & 88 & 0.5 & & & \\
\hline Hematite & 12.9 & $2.5 \times 10^{-15}$ & 66.2 & $4.1 \times 10^{-10}$ & 66.2 & 1 & & & \\
\hline Magnesite & 9.1 & $4.6 \times 10^{-10}$ & 23.5 & $4.2 \times 10^{-7}$ & 14.4 & 1 & & & \\
\hline Dolomite & 9.1 & $3.0 \times 10^{-8}$ & 52.2 & $6.5 \times 10^{-4}$ & 36.1 & 0.5 & & & \\
\hline Low-albite & 9.1 & $2.8 \times 10^{-13}$ & 69.8 & $6.9 \times 10^{-11}$ & 65 & 0.457 & $2.5 \times 10^{-16}$ & 71 & -0.572 \\
\hline Siderite & 9.1 & $1.3 \times 10^{-9}$ & 62.76 & $6.5 \times 10^{-4}$ & 36.1 & 0.5 & & & \\
\hline Ankerite & 9.1 & $1.3 \times 10^{-9}$ & 62.76 & $6.5 \times 10^{-4}$ & 36.1 & 0.5 & & & \\
\hline Dawsonite & 9.1 & $1.3 \times 10^{-9}$ & 62.76 & $6.5 \times 10^{-4}$ & 36.1 & 0.5 & & & \\
\hline Ca-smectite & 108.7 & $1.7 \times 10^{-13}$ & 35 & $1.0 \times 10^{-11}$ & 23.6 & 0.34 & $3.0 \times 10^{-17}$ & 58.9 & -0.4 \\
\hline Alunite & 9.1 & $1.0 \times 10^{-12}$ & 57.78 & & & & $1.0 \times 10^{-12}$ & 7.5 & -1.0 \\
\hline Pyrite & 12.9 & $\begin{array}{l}\mathrm{k}_{25}=2.8 \times 10 \\
\mathrm{E}_{\mathrm{a}}=56.9 \\
\mathrm{n}\left(\mathrm{O}_{2}(\mathrm{aq})\right)=\end{array}$ & & $\begin{array}{l}\mathrm{k}_{25}=3.0 \times 1 \\
\mathrm{E}_{\mathrm{a}}=56.9 \\
\mathrm{n}\left(\mathrm{H}^{+}\right)=-0.5\end{array}$ & $\mathrm{n}(\mathrm{F}$ & $=0.5$ & & & \\
\hline
\end{tabular}




\section{REFERENCES}

Balistrieri, L.S., 1998. Preliminary estimates of benthic fluxes of dissolved metals in Coeur d'Alene Lake, Idaho. Open File Report 98-793, U.S. Geological Survey, Seattle, WA, 40pp.

Curtis, G.P., 2003. Comparison of approaches for simulating reactive solute transport involving organic degradation reactions by multiple terminal electron acceptors. Computers \& Geosciences 29, 319-329.

Doughty, C., Freifeld, B.M., Trautz, R.C., 2008. Site characterization for $\mathrm{CO}_{2}$ geologic storage and vice versa - the Frio brine pilot, Texas, USA as a case study. Environmental Geology 54, 1635-1656.

Dzombak, D.A. Morel, F.M.M., 1990. Surface Complexation Modeling-Hydrous Ferric Oxide. John Wiley \& Sons, New York, 393 pp.

Freifeld, B.M., Trautz, R.C., Kharaka, Y.K., Phelps, T.J., Myer, L.R., Hovorka, S.D., Collins, D.J., 2005. The U-tube: A novel system for acquiring borehole fluid samples from a deep geologic $\mathrm{CO}_{2}$ sequestration experiment. Journal of Geophysical Research 110, B10203.

Gwo, J.P., Jardine, P.M., Wilson, G.V., Yeh, G.T.. 1996. Using a multiregion model to study the effects of advective and diffusive mass transfer on local physical nonequilibrium and solute mobility in a structured soil. Water Resource Research 32, 561-570.

Horowitz, A.J., Elrick, K.A., Robbins, J.A., Cook, R.B., 1995. Effect of mining and related activities on sediment trace element geochemistry of Lake Coeur D’Alene, Idaho, USA Part II: Subsurface sediments. Hydrological Process 9, 35-54.

Hovorka, S.D., Benson, S.M., Doughty, C.K., Freifeld, B.M., Sakurai, S., Daley, T.M., Kharaka, Y.K., Holtz, M.H., Trautz, R.C., Nance, H.S., Myer, L.R., Knauss, K.G., 2006. Measuring permanence of $\mathrm{CO}_{2}$ storage in saline formations-The Frio experiment. Environmental Geosciences 13, 103-119.

Lasaga, A.C., Soler, J.M., Ganor, J., Burch, T.E., Nagy, K.L., 1994. Chemical weathering rate laws and global geochemical cycles. Geochimica et Cosmochimica Acta 58, 2361-2386.

Lichtner, P.C., 1988. The quasi-stationary state approximation to coupled mass transport and fluid-rock interaction in a porous medium. Geochimica et Cosmochimica Acta 52, 143-165.

Liger, E., Charlet L., Van Cappellen, P., 1999. Surface catalysis of U(VI) reduction by Fe(II). Geochimica et Cosmochimica Acta 63, 2939-2955. 
Kuwabara, J.S., Carter, J.L., Topping, B.R., Fend, S.B., 2003. Importance of sediment-water interactions in Coeur d'Alene Lake, Idaho, USA: management implications. Environmental Management 32, 348-359.

Moberly, J.G., Borch T., Sani R.K., Spycher N.F., Şengör S.S., Ginn T.R., Peyton, B.M., 2009. Heavy metal-mineral associations in Coeur d'Alene river sediments: A synchrotron-based analysis. Water, Air, and Soil Pollution 200, 195-208.

Narasimhan, T.N., Witherspoon, P.A., 1976. An integrated finite difference method for analyzing fluid flow in porous media, Water Resources Research 12, 57-64.

Palandri, J., Kharaka, Y.K., 2004. A compilation of rate parameters of water-mineral interaction kinetics for application to geochemical modeling. Open File Report 2004-1068, U.S. Geological Survey, Menlo Park, CA, 64pp.

Parkhurst, D.L., Appelo, C.A.J., 1999. User's Guide to PHREEQC (Version 2) - A computer program for speciation, batch-reaction, one-dimensional transport, and inverse geochemical calculations. Water-Resources Investigations Report 99-4259, U.S. Geological Survey, Denver, CO. 312pp.

Pruess, K., 2004. The TOUGH codes: A family of simulation tools for multiphase flow and transport processes in permeable media. Vadose Zone Journal 3, 738-746.

Pruess, K., Spycher, N., 2007. ECO2N - A fluid property module for the TOUGH2 code for studies of $\mathrm{CO}_{2}$ storage in saline aquifers. Energy Conversion and Management 48(6), 17611767.

Rickard, D., 1995. Kinetics of FeS precipitation: Par 1. Competing reaction mechanisms. Geochimica et Cosmochimica Acta 59, 4367-4379.

Sengör, S.S., Spycher, N.F., Ginn, T.R., Moberly, J., Peyton, B., Sani, R.K., 2007a. Reductive dissolution and metal transport in Lake Coeur d'Alene sediments, In: Bullen T., Wang Y., (eds.) Water-Rock Interaction, WRI-12, Taylor \& Francis, New York, p. 895-899.

Sengör, S.S., Spycher, N.F., Ginn, T.R., Sani, R.K., Peyton, B., 2007b. Biogeochemical reactivediffusive transport of heavy metals in Lake Coeur d'Alene sediments. Applied Geochemistry 22, 2569-2594.

Sonnenthal E., Ito, A., Spycher, N., Yui, M., Apps, J., Sugita, Y., Conrad, M., Kawakami, S., 2005. Approaches to modeling coupled thermal, hydrological, and chemical processes in the Drift Scale Heater Test at Yucca Mountain. International Journal of Rock Mechanics and Mining Sciences 42, 6987-719. 
Spycher, N.F., Sonnenthal, E.L., Apps, J.A., 2003. Fluid flow and reactive transport around potential nuclear waste emplacement tunnels at Yucca Mountain, Nevada. Journal of Contaminant Hydrology 62-63, 653-673.

Steefel, C.I., MacQuarrie, K.T.B., 1996. Approaches to modeling of reactive transport in porous media, In: Lichtner, P.C., Steefel, C.I., Oelkers, E.H. (eds.), Reactive transport in porous media, Reviews in Mineralogy, Mineral Society of America 34, p. 83-129.

Toevs, G.R., Morra, M.J., Polizzotto, M.L., Strawn, D.G., Bostick, B.C., Fendorf, S., 2006. Metal(loid) diagenesis in mine-impacted sediments of Lake Coeur d'Alene, Idaho. Environmental Science and Technology 40, 2537-2543.

Van Cappellen, P., Gaillard, P., 1996. Biogeochemical dynamics in aquatic sediments, In: Lichtner, P.C., Steefel, C.I., Oelkers, E.H. (eds.) Reactive transport in porous media, Reviews in Mineralogy, Mineral Society of America 34, p. 335-376.

Van Genuchten, M. Th., 1980. A Closed-form equation for predicting the hydraulic conductivity of unsaturated soils. Journal of American Soil Science Society 44, $892-898$.

Winowiecki, L., 2002. Geochemical cycling of heavy metals in the sediment of Lake Coeur d'Alene, Idaho. Masters Thesis, University of Idaho, Moscow, Idaho. 236pp.

$\mathrm{Xu}, \mathrm{T} ., 2008$. Incorporation of aqueous reaction kinetics and biodegradation into TOUGHREACT: Application of a multi-region model to hydrobiogeochemical transport of denitrification and sulfate reduction. Vadose Zone Journal 7, 305-315.

Xu, T., Apps, J.A., Pruess, K., Yamamoto, H., 2007. Numerical modeling of injection and mineral trapping of $\mathrm{CO}_{2}$ with $\mathrm{H}_{2} \mathrm{~S}$ and $\mathrm{SO}_{2}$ in a sandstone formation. Chemical Geology 242, 319-346.

Xu, T., Pruess, K., 2001. Modeling multiphase non-isothermal fluid flow and reactive geochemical transport in variably saturated fractured rocks: 1. Methodology. American Journal of Science 301, 16-33.

Xu, T., Sonnenthal, E.L., Spycher, N., Pruess, K. 2006. TOURGHREACT: A simulation program for non-isothermal multiphase reactive geochemical transport in variably saturated geologic media. Computers \& Geosciences 32, 145-165.

Yeh, G.T., Tripathi, V.S., 1991. A model for simulating transport of reactive multispecies components: model development and demonstration. Water Resources Research 27, 30753094.

Zhang, G., Spycher, N., Sonnenthal, E., Steefel, C., Xu, T., 2008. Modeling reactive multiphase flow and transport of concentrated aqueous solutions. Nuclear Technology 164, 180-195. 
Zheng, L., Apps, J.A., Zhang, Y., Xu, T., Birkholzer, J., 2009. On mobilization of lead and arsenic in groundwater in response to $\mathrm{CO}_{2}$ leakage from deep geological storage. Chemical Geology 268, 281-297. 
Figure 1. Space discretization and geometric data for integral finite difference method.

Figure 1. Subgridding in method of "multiple interacting continua" (MINC).

Figure 2. Schematic representation of a multi-region model for resolving local diffusive transport.

Figure 3. Schematic representation of 2-D radial flow model for supercritical $\mathrm{CO}_{2}$ injection into a sandstone formation.

Figure 4. Distribution of supercritical $\mathrm{CO}_{2}$ gas phase saturation ( $\mathrm{Sg}$ ) at different times for 2-D radial model (depths appear in negative number, indicating the distance below the top of the model domain, or caprock).

Figure 5. Distribution of total dissolved $\mathrm{CO}_{2}\left(\mathrm{~mol} / \mathrm{kg} \mathrm{H}_{2} \mathrm{O}\right)$ and $\mathrm{pH}$ at different times for 2-D radial model.

Figure 6. Changes of volume fraction of siderite and ankerite after 1,000 years.

Figure 7. Distribution of porosity after 1,000 years.

Figure 8. Percentage of amounts of $\mathrm{CO}_{2}$ trapped in different phases over time.

Figure 9. Conceptual 1D diffusive biogeochemical model (Sengör et al, 2007b)

Figure 10. Concentrations of key parameters, redox species, and metals with depth from the top of the sediment column. Lines show computed values, symbols (Summer 2001: triangle symbols; Fall 2001: square symbols) are measured values by Winowiecki (2002), except for $\mathrm{Cu}$ (average over interval shown, from Sengör et al. 2007b).

Figure 11. Computed change in abundance of $\mathrm{Fe}$ minerals from the top of the sediment column. The reductive dissolution of ferrihydrite leads to an increase in Fe(II) (Figure 10) and subsequent FeS and siderite precipitation. 
Table 1. Hydrogeological parameters for the 2-D radial $\mathrm{CO}_{2}$ injection problem.

\begin{tabular}{|c|c|}
\hline $\begin{array}{l}\text { Aquifer thickness } \\
\text { Permeability (horizontal) } \\
\text { Permeability (vertical) } \\
\text { Porosity } \\
\text { Compressibility } \\
\text { Temperature } \\
\text { Pressure } \\
\text { Salinity } \\
\mathrm{CO}_{2} \text { injection rate } \\
\end{array}$ & $\begin{array}{l}40 \mathrm{~m} \\
1.0 \times 10^{-13} \mathrm{~m}^{2} \\
1.0 \times 10^{-14} \mathrm{~m}^{2} \\
0.3 \\
4.5 \times 10^{-10} \mathrm{~Pa}^{-1} \\
75^{0} \mathrm{C} \\
200 \mathrm{bar} \\
0.06(\mathrm{NaCl} \text { mass fraction }) \\
20 \mathrm{~kg} / \mathrm{s}\end{array}$ \\
\hline Relative permeability & \\
\hline $\begin{array}{l}\text { Liquid (van Genuchten, 1980): } \\
\qquad \mathrm{k}_{\mathrm{rl}}=\sqrt{\mathrm{S}^{*}}\left\{1-\left(1-\left[\mathrm{S}^{*}\right]^{1 / \mathrm{m}}\right)^{\mathrm{m}}\right\}^{2} \\
\text { irreducible water saturation } \\
\text { exponent }\end{array}$ & $\begin{array}{l}\mathrm{S}^{*}=\left(\mathrm{S}_{1}-\mathrm{S}_{\mathrm{lr}}\right) /\left(1-\mathrm{S}_{\mathrm{lr}}\right) \\
\mathrm{S}_{\mathrm{lr}}=0.30 \\
\mathrm{~m}=0.457\end{array}$ \\
\hline Gas (Corey, 1954): & \\
\hline $\begin{array}{l}\mathrm{k}_{\mathrm{rg}}=(1-\widehat{\mathrm{S}})^{2}\left(1-\widehat{\mathrm{S}}^{2}\right) \\
\text { irreducible gas saturation }\end{array}$ & $\begin{array}{l}\widehat{S}=\frac{\left(S_{1}-S_{\text {Ir }}\right)}{\left(S_{1}-S_{\text {lr }}-S_{g r}\right)} \\
S_{g r}=0.05\end{array}$ \\
\hline Capillary pressure & \\
\hline $\begin{array}{l}\text { Van Genuchten }(1980) \\
\mathrm{P}_{\text {cap }}=-\mathrm{P}_{0}\left(\left[\mathrm{~S}^{*}\right]^{-1 / \mathrm{m}}-1\right)^{1-\mathrm{m}} \\
\text { irreducible water saturation } \\
\text { exponent } \\
\text { strength coefficient }\end{array}$ & $\begin{array}{l}\mathrm{S}^{*}=\left(\mathrm{S}_{1}-\mathrm{S}_{\mathrm{lr}}\right) /\left(1-\mathrm{S}_{\mathrm{lr}}\right) \\
\mathrm{S}_{\mathrm{lr}}=0.03 \\
\mathrm{~m}=0.457 \\
\mathrm{P}_{0}=19.61 \mathrm{kPa}\end{array}$ \\
\hline
\end{tabular}


Table 2. Initial mineral volume fractions and possible secondary mineral phases used in the simulations.

\begin{tabular}{|c|c|c|c|}
\hline \multirow[t]{2}{*}{ Mineral } & \multirow[t]{2}{*}{ Chemical formula } & \multicolumn{2}{|c|}{ Volume percent } \\
\hline & & of solid & of medium \\
\hline \multicolumn{4}{|l|}{ Primary: } \\
\hline Quartz & $\mathrm{SiO}_{2}$ & 58 & 40.6 \\
\hline Kaolinite & $\mathrm{Al}_{2} \mathrm{Si}_{2} \mathrm{O}_{5}(\mathrm{OH})_{4}$ & 2.02 & 1.41 \\
\hline Calcite & $\mathrm{CaCO}_{3}$ & 1.93 & 1.35 \\
\hline Illite & $\mathrm{K}_{0.6} \mathrm{Mg}_{0.25} \mathrm{Al}_{1.8}\left(\mathrm{Al}_{0.5} \mathrm{Si}_{3.5} \mathrm{O}_{10}\right)(\mathrm{OH})_{2}$ & 1.0 & 0.7 \\
\hline Oligoclase & $\mathrm{Ca}_{0.2} \mathrm{Na}_{0.8} \mathrm{Al}_{1.2} \mathrm{Si}_{2.8} \mathrm{O}_{8}$ & 19.8 & 13.86 \\
\hline K-feldspar & $\mathrm{KAlSi}_{3} \mathrm{O}_{8}$ & 8.2 & 5.74 \\
\hline Na-smectite & $\mathrm{Na}_{0.290} \mathrm{Mg}_{0.26} \mathrm{Al}_{1.77} \mathrm{Si}_{3.97} \mathrm{O}_{10}(\mathrm{OH})_{2}$ & 4 & 2.8 \\
\hline Chlorite & $\mathrm{Mg}_{2.5} \mathrm{Fe}_{2.5} \mathrm{Al}_{2} \mathrm{Si}_{3} \mathrm{O}_{10}(\mathrm{OH})_{8}$ & 4.55 & 3.19 \\
\hline Hematite & $\mathrm{Fe}_{2} \mathrm{O}_{3}$ & 0.5 & 0.35 \\
\hline Porosity & & ---- & 30 \\
\hline \multicolumn{4}{|l|}{ Secondary: } \\
\hline Anhydrite & $\mathrm{CaSO}_{4}$ & & \\
\hline Magnesite & $\mathrm{MgCO}_{3}$ & & \\
\hline Dolomite & $\mathrm{CaMg}\left(\mathrm{CO}_{3}\right)_{2}$ & & \\
\hline Low-albite & $\mathrm{NaAlSi}_{3} \mathrm{O}_{8}$ & & \\
\hline Siderite & $\mathrm{FeCO}_{3}$ & & \\
\hline Ankerite & $\mathrm{CaMg}_{0.3} \mathrm{Fe}_{0.7}\left(\mathrm{CO}_{3}\right)_{2}$ & & \\
\hline Dawsonite & $\mathrm{NaAlCO}_{3}(\mathrm{OH})_{2}$ & & \\
\hline Ca-smectite & $\mathrm{Ca}_{0.145} \mathrm{Mg}_{0.26} \mathrm{Al}_{1.77} \mathrm{Si}_{3.97} \mathrm{O}_{10}(\mathrm{OH})_{2}$ & & \\
\hline Alunite & $\mathrm{KAl}_{3}(\mathrm{OH})_{6}\left(\mathrm{SO}_{4}\right)_{2}$ & & \\
\hline Pyrite & $\mathrm{FeS}_{2}$ & & \\
\hline
\end{tabular}


Table 3. Initial total dissolved component concentrations for reactive transport simulations. Iron is the sum of $\mathrm{Fe}^{2+}, \mathrm{Fe}^{3+}$ and their related complexes. Carbon is the sum of $\mathrm{CO}_{2}(\mathrm{aq}), \mathrm{CH}_{4}(\mathrm{aq})$, and their related species such as $\mathrm{HCO}_{3}{ }^{-}$and acetic acid(aq). Sulfur is the sum of sulfate and sulfide species

\begin{tabular}{|l|l|}
\hline \multicolumn{1}{|c|}{ Component } & \multicolumn{1}{|c|}{$\begin{array}{c}\text { Concentration } \\
\end{array}$} \\
& \\
& $\left(\mathrm{mol} / \mathrm{kg} \mathrm{H} \mathrm{H}_{2} \mathrm{O}\right)$ \\
$\mathrm{Ca}^{2+}$ & $6.6 \times 10^{-2}$ \\
$\mathrm{Mg}^{2+}$ & $2.2 \times 10^{-2}$ \\
$\mathrm{Na}^{+}$ & 1.35 \\
$\mathrm{~K}^{+}$ & $4.53 \times 10^{-3}$ \\
$\mathrm{Iron}^{+}$ & $4.63 \times 10^{-4}$ \\
$\mathrm{SiO}_{2}(\mathrm{aq})$ & $2.50 \times 10^{-4}$ \\
$\mathrm{Carbon}^{-4}$ & $5.04 \times 10^{-2}$ \\
$\mathrm{Sulur}$ & $4.20 \times 10^{-5}$ \\
$\mathrm{Al}^{3+}$ & $1.56 \times 10^{-8}$ \\
$\mathrm{Cl}^{-}$ & 1.49 \\
& \\
$\mathrm{pH}$ & 6.7 \\
Temperature & $75^{\circ} \mathrm{C}$ \\
& \\
\hline
\end{tabular}


Table 4. Microbial reactions and rate laws (from Sengör et al., 2007a). See Table 5 for parameter values.

\begin{tabular}{|c|c|}
\hline \\
\hline \multicolumn{2}{|l|}{$\mathrm{CH}_{3} \mathrm{COO}^{-}+2 \mathrm{O}_{2} \rightarrow 2 \mathrm{CO}_{3}^{-2}+3 \mathrm{H}^{+}$} \\
\hline $\mathrm{CH}_{3} \mathrm{COO}^{-}+1.6 \mathrm{NO}_{3}^{-} \rightarrow 2 \mathrm{CO}_{3}^{-2}+0.8 \mathrm{~N}_{2}+1.4 \mathrm{H}^{+}+0.8 \mathrm{H}_{2} \mathrm{O}$ & $R_{\mathrm{NO}}$ \\
\hline $\mathrm{CH}_{3} \mathrm{COO}^{-}+8 \mathrm{Fe}^{+3}+4 \mathrm{H}_{2} \mathrm{O} \rightarrow 8 \mathrm{Fe}^{+2}+2 \mathrm{CO}_{3}^{-2}+11 \mathrm{H}^{+}$ & $R_{F e+3}$ \\
\hline $\mathrm{CH}_{3} \mathrm{COO}^{-}+\mathrm{SO}_{4}^{-2} \rightarrow 2 \mathrm{CO}_{3}^{-2}+\mathrm{HS}^{-}+2 \mathrm{H}^{+}$ & $R_{\mathrm{SO} 4-2}$ \\
\hline $\begin{array}{l}\text { Kinetic rate laws: } \\
R_{O 2}=V_{m}{ }^{O 2} \frac{\left[O_{2}\right]}{\left[O_{2}\right]+K_{s}^{O 2}}\end{array}$ & \\
\hline$R_{\mathrm{NO3}}=V_{m}{ }^{N O 3} \frac{\left[\mathrm{NO}_{3}\right]}{\left[\mathrm{NO}_{3}\right]+K_{s}^{N O 3}} \frac{K_{O 2}^{i n}}{K_{O 2}^{i n}+\left[\mathrm{O}_{2}\right]}$ & \\
\hline$R_{\mathrm{Fe}+3}{ }^{(*)}=V_{m}^{F e} \frac{K_{\mathrm{O} 2}^{i n}}{K_{\mathrm{O} 2}^{i n}+\left[\mathrm{O}_{2}\right]} \frac{K_{\mathrm{NO} 3}^{\text {in }}}{K_{\mathrm{NO} 3}^{\text {in }}+\left[\mathrm{NO}_{3}\right]}$ & \\
\hline 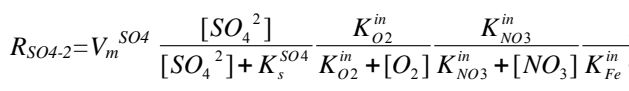 & $\frac{K_{F e}^{i n}}{+\left[F e^{+3}\right]}$ \\
\hline $\begin{array}{ll}V_{m}^{i} & \text { Maximum substrate utilization rate constant } \\
K_{s}^{i} & \text { Half saturation constant } \\
K_{i}^{i n} & \text { Inhibition constants } \\
\left(^{*}\right) & \text { Assumes unlimited } \mathrm{Fe}^{+3} \text { supply from abundant solid Fe hydr }\end{array}$ & oxides \\
\hline
\end{tabular}

Table 5. Values of parameters in Table 4 (from Sengör et al., 2007a, except for $V_{m}{ }^{F e}$ ). The value of $V_{m}{ }^{F e}$ was recalibrated to take into account the effect $\mathrm{Fe}(\mathrm{II})$ sorption onto ferrihydrite, which was ignored in the original model.

\begin{tabular}{|ll|l|}
\hline \multicolumn{2}{|l|}{ Parameter (units) } & Model Value \\
\hline$V_{m}{ }^{\mathrm{O}}$ & $\left(\mathrm{s}^{-1}\right)$ & $5 \times 10^{-9}$ \\
$V_{m}{ }^{N O 3}$ & $\left(\mathrm{~s}^{-1}\right)$ & $2 \times 10^{-10}$ \\
$V_{m}{ }^{\mathrm{Fe}}$ & $\left(\mathrm{s}^{-1}\right)$ & $15 \times 10^{-12}$ \\
$V_{m}{ }^{\mathrm{SO} 4}$ & $\left(\mathrm{~s}^{-1}\right)$ & $3 \times 10^{-9}$ \\
$K_{s}^{\mathrm{O} 2}$ & (molal) & $2.41 \times 10^{-5}$ \\
$K_{s}^{N O 3}$ & (molal) & $1.13 \times 10^{-4}$ \\
$K_{s}^{\mathrm{SO} 4}$ & (molal) & $1 \times 10^{-3}$ \\
$K_{\mathrm{O} 2}{ }^{\text {in }}$ & (molal) & $1.61 \times 10^{-8}$ \\
$K_{\mathrm{NO} 3}$ & (molal) & $1 \times 10^{-7}$ \\
$K_{\mathrm{Fe}}{ }^{i n}$ & (molal) & $1 \times 10^{-8}$ \\
& & \\
\hline
\end{tabular}


Table 6. Minerals included in the simulation, and reaction constraints.

\begin{tabular}{|llll|}
\hline Mineral & $\begin{array}{l}\text { Initial Amount } \\
\text { Volume })\end{array}$ & Constraint on reaction & $\begin{array}{c}k \times A \\
\left(\mathrm{~mol} \mathrm{~s}^{-1} \mathrm{~kg}^{-1} \text { water }\right)\end{array}$ \\
Ferrihydrite & 1.4 & Equilibrium & none \\
$\mathrm{FeS}$ & none & Equilibrium & none \\
Siderite & 10 & $R_{\mathrm{FeCO} 3}=k A(Q / K-1)$ & $5 \times 10^{-14}$ \\
Sphalerite $^{1}$ & none & $R_{\mathrm{ZnS}}=k A\left[\mathrm{Zn}^{+2}\right]\left[\mathrm{H}_{2} \mathrm{~S}\right](\mathrm{Q} / \mathrm{K}-1)^{0.01}$ & $2.7 \times 10^{-3}$ \\
Galena $^{1}$ & none & $R_{\mathrm{PbS}}=k A\left[\mathrm{~Pb}^{+2}\right]\left[\mathrm{H}_{2} \mathrm{~S}\right](\mathrm{Q} / \mathrm{K}-1)^{0.01}$ & $2.7 \times 10^{-3}$ \\
Chalcocite $^{1}$ & none & $R_{\mathrm{Cu2S}}=k A\left[\mathrm{Cu}^{+}\right]\left[\mathrm{H}_{2} \mathrm{~S}\right](\mathrm{Q} / \mathrm{K}-1)^{0.01}$ & $2.7 \times 10^{-3}$ \\
\hline
\end{tabular}

For each mineral, $k$ and $A$ represent the rate constant and reactive surface area, respectively, and $Q$ and $K$ represent the activity product and solubility product, respectively. Values of $k \times A$ were roughly calibrated, and intentionally kept low for heavy metal sulfides, which are only used here as "proxies" for precipitation in various sulfide forms. The form of the rate law for sulfides is after Rickard (1995), except for the $(1-Q / K)$ term, which was added to ensure the rate convergence to zero at equilibrium. The small exponent on this term is meant to keep it near 1 except at equilibrium when this term drops to 0 .

Table 7. Input water composition (oxic lake water, from Sengör et al., 2007a)

$\begin{array}{lrl}\text { Component } & \text { Concentration } & \text { Units } \\ \mathrm{pH}\left(25^{\circ} \mathrm{C}\right) & 7.2 & \\ \mathrm{Cl} & 1.95 \times 10^{-5} & \text { molal } \\ \mathrm{CO}_{3 \text { (tot })} & 3.54 \times 10^{-4} & \text { molal } \\ \mathrm{SO}_{4} & 5.83 \times 10^{-5} & \text { molal } \\ \mathrm{Ca} & 1.37 \times 10^{-4} & \text { molal } \\ \mathrm{Mg} & 8.64 \times 10^{-5} & \text { molal } \\ \mathrm{Na} & 1.00 \times 10^{-4} & \text { molal } \\ \mathrm{K} & 1.28 \times 10^{-5} & \text { molal } \\ \mathrm{NO}_{3} & 8.00 \times 10^{-5} & \text { molal } \\ \mathrm{O}_{2(\mathrm{aq})} & 4.25 \times 10^{-4} & \text { molal } \\ \mathrm{Fe} & 3.11 \times 10^{-9} & \text { molal } \\ \mathrm{Pb} & 5.31 \times 10^{-8} & \text { molal } \\ \mathrm{Zn} & 8.72 \times 10^{-6} & \text { molal } \\ \mathrm{Cu} & 1.18 \times 10^{-8} & \text { molal }\end{array}$




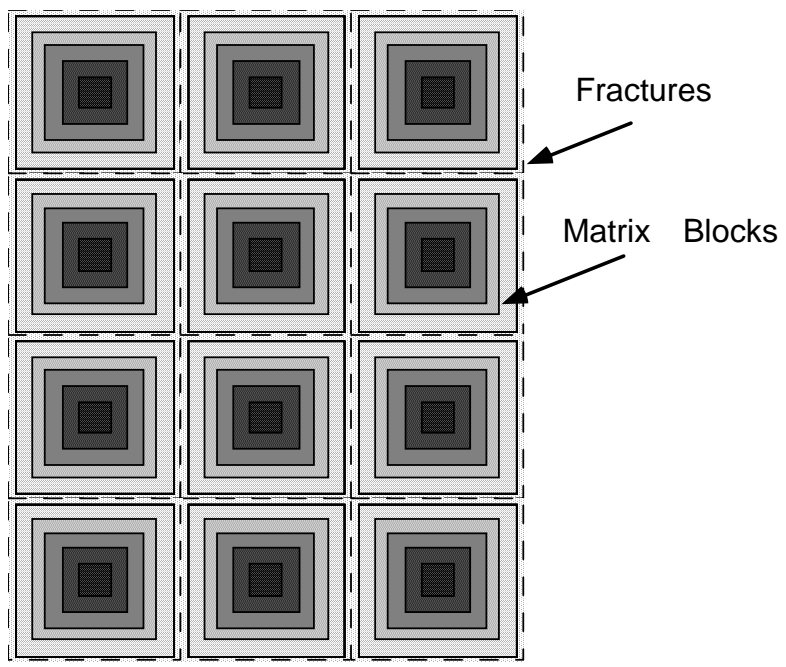

Figure 1. Subgridding in method of "multiple interacting continua" (MINC). 


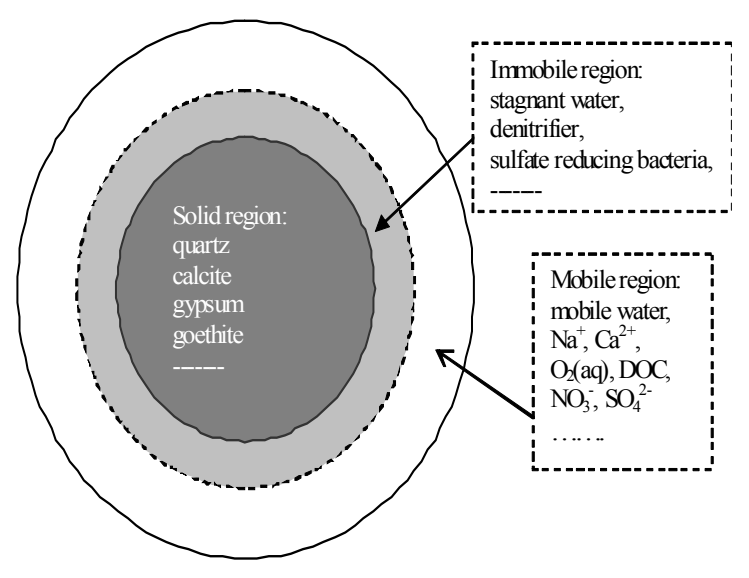

Figure 2. Schematic representation of a multi-region model for resolving local diffusive transport.

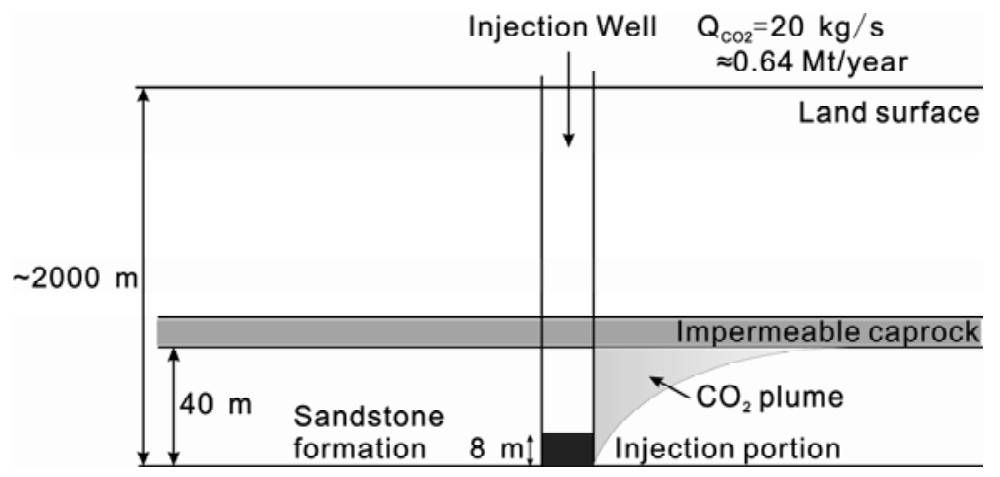

Figure 3. Schematic representation of 2-D radial flow model for supercritical $\mathrm{CO}_{2}$ injection into a sandstone formation. 


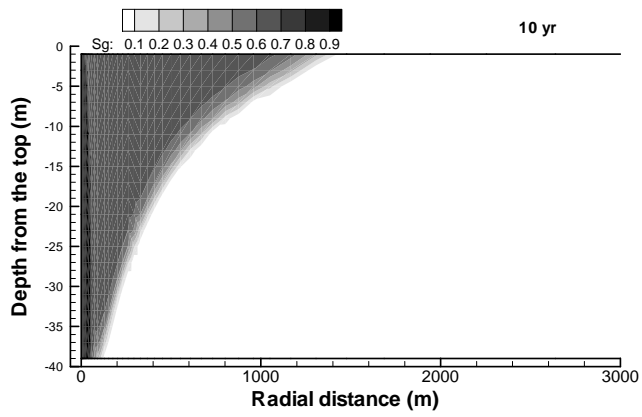

(a) 10 years

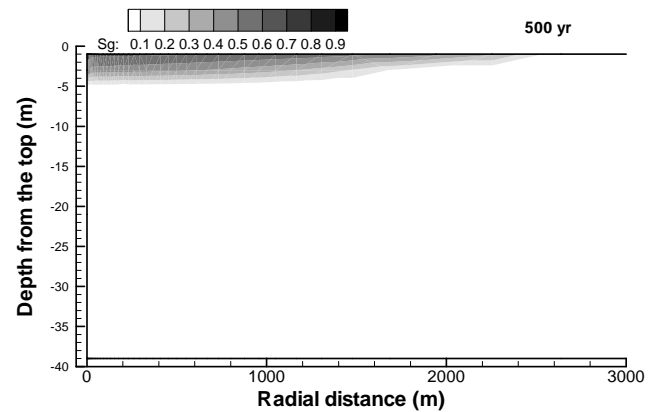

(b) 100 years

Figure 4. Distribution of supercritical $\mathrm{CO}_{2}$ gas phase saturation ( $\mathrm{Sg}$ ) at different times for 2-D radial model (depths appear in negative number, indicating the distance below the top of the model domain, or caprock).

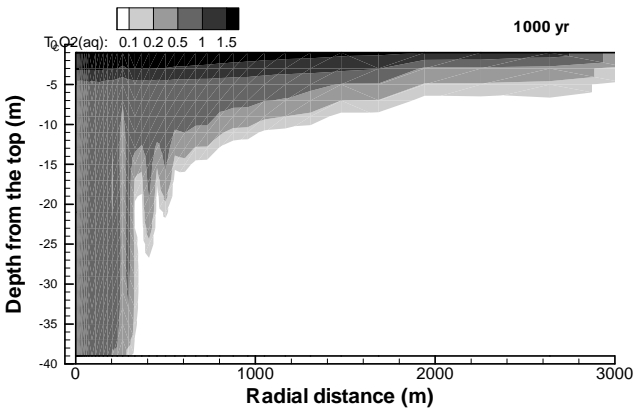

(a) Dissolved $\mathrm{CO}_{2}$

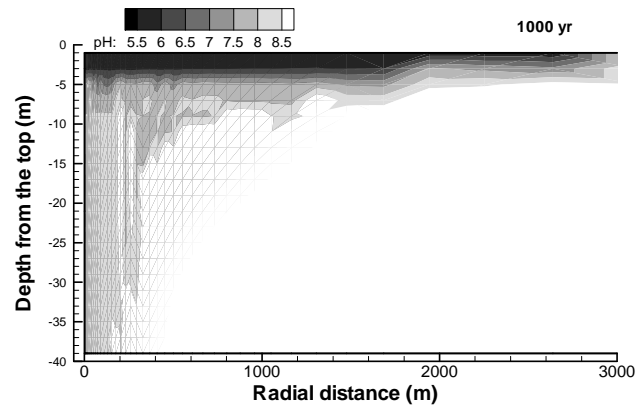

(b) $\mathrm{pH}$

Figure 5. Distribution of total dissolved $\mathrm{CO}_{2}\left(\mathrm{~mol} / \mathrm{kg} \mathrm{H}_{2} \mathrm{O}\right)$ and $\mathrm{pH}$ at different times for 2-D radial model. 


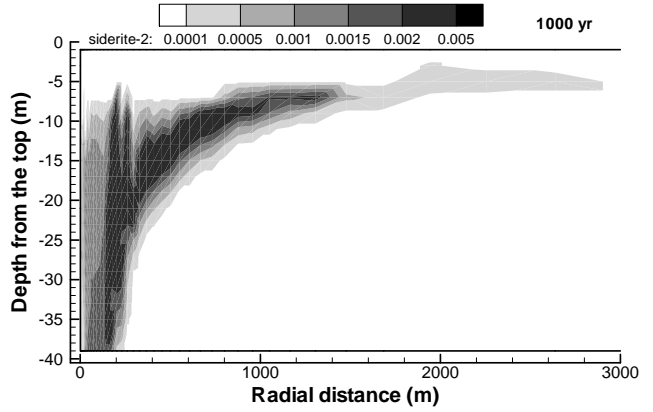

(a) Siderite

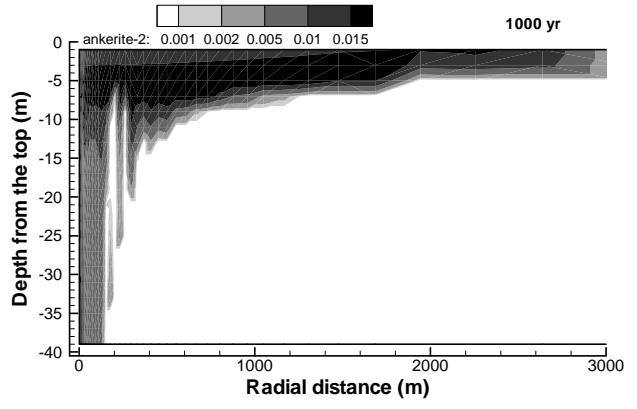

(b) Ankerite

Figure 6. Changes of volume fraction of siderite and ankerite after 1,000 years.

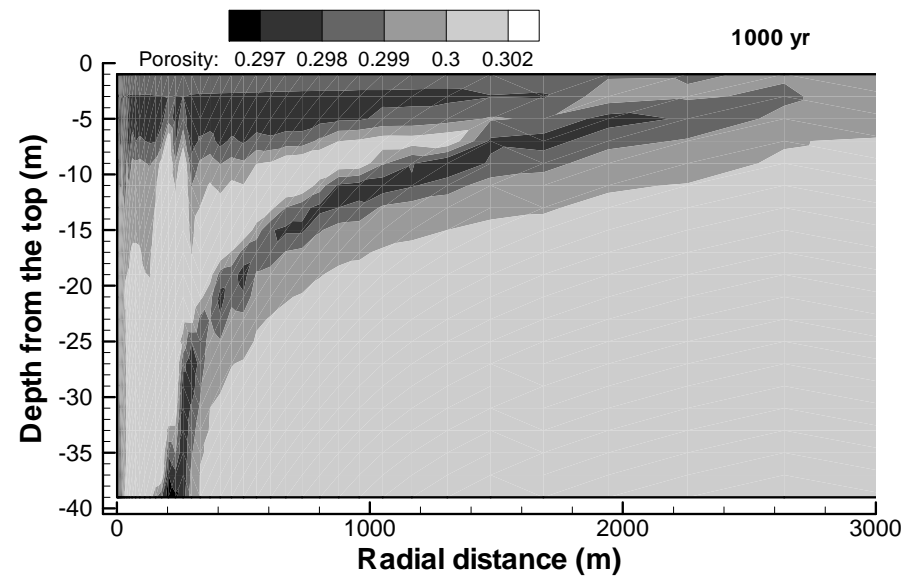

Figure 7. Distribution of porosity after 1,000 years. 


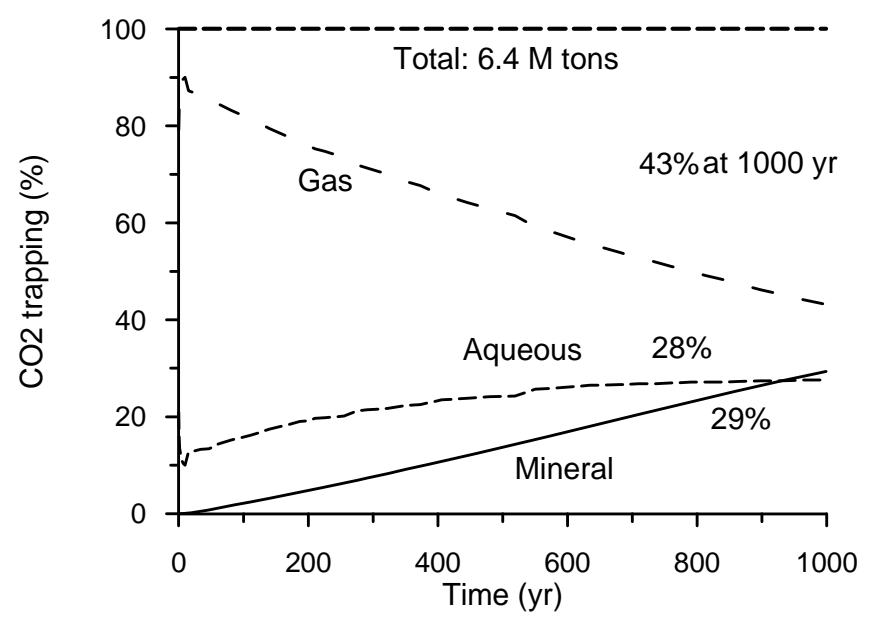

Figure 8. Percentage of amounts of $\mathrm{CO}_{2}$ trapped in different phases over time.

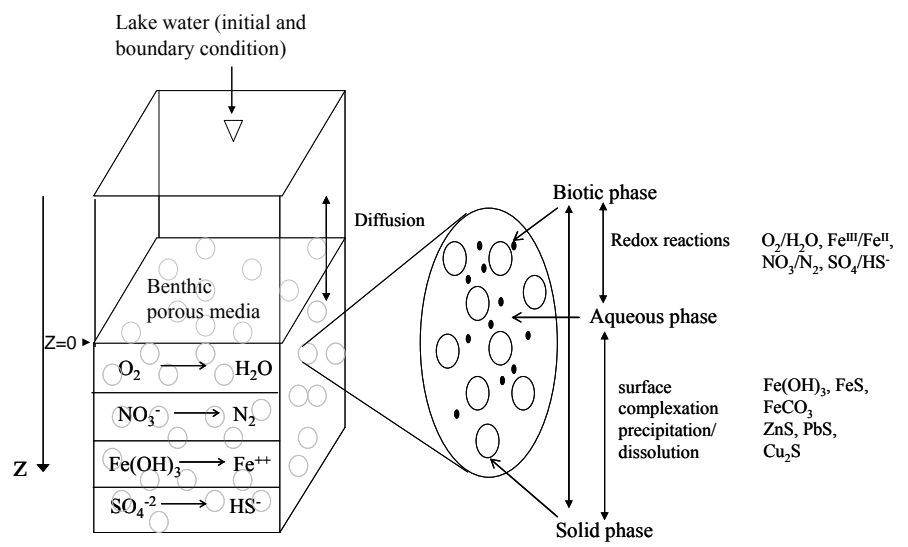

Figure 9. Conceptual 1D diffusive biogeochemical model (Sengor et al, 2007b) 

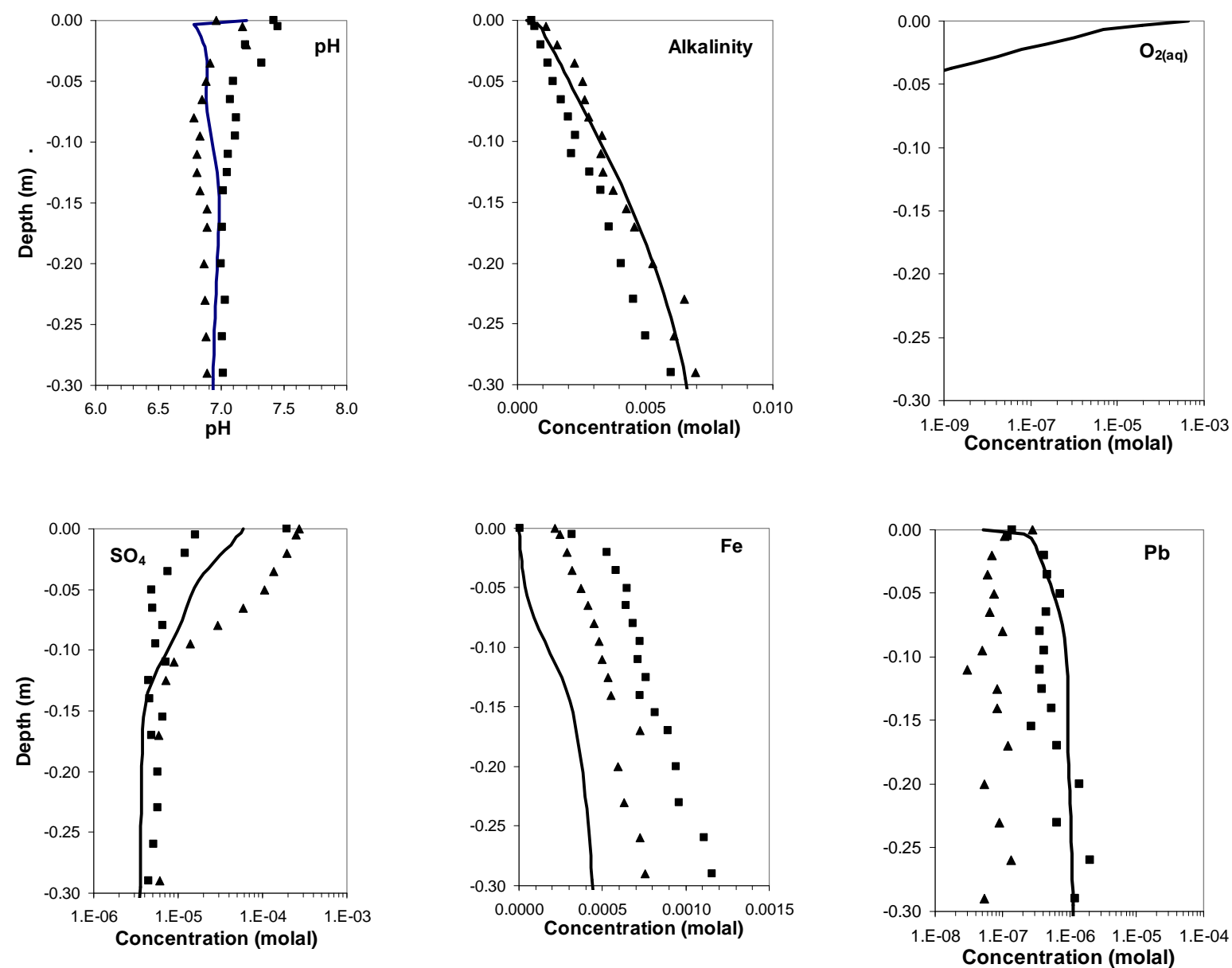

Figure 10. Concentrations of key parameters, redox species, and metals with depth from the top of the sediment column. Lines show computed values, symbols (Summer 2001: triangle symbols; Fall 2001: square symbols) are measured values by Winowiecki (2002), except for $\mathrm{Cu}$ (average over interval shown, from Sengor et al. 2007b). 


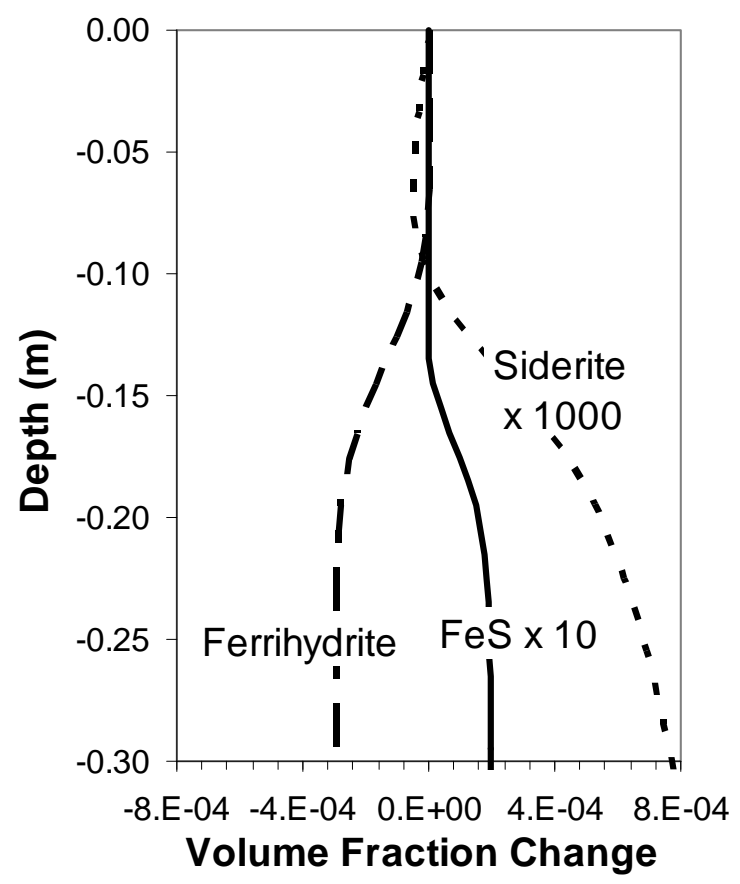

Figure 11. Computed change in abundance of $\mathrm{Fe}$ minerals from the top of the sediment column. The reductive dissolution of ferrihydrite leads to an increase in Fe(II) (Figure 10) and subsequent FeS and siderite precipitation. 


\section{DISCLAIMER}

This document was prepared as an account of work sponsored by the United States Government. While this document is believed to contain correct information, neither the United States Government nor any agency thereof, nor The Regents of the University of California, nor any of their employees, makes any warranty, express or implied, or assumes any legal responsibility for the accuracy, completeness, or usefulness of any information, apparatus, product, or process disclosed, or represents that its use would not infringe privately owned rights. Reference herein to any specific commercial product, process, or service by its trade name, trademark, manufacturer, or otherwise, does not necessarily constitute or imply its endorsement, recommendation, or favoring by the United States Government or any agency thereof, or The Regents of the University of California. The views and opinions of authors expressed herein do not necessarily state or reflect those of the United States Government or any agency thereof or The Regents of the University of California.

Ernest Orlando Lawrence Berkeley National Laboratory is an equal opportunity employer. 